\title{
OXIDATIVE STRESS IN THE HEART OF RATS EXPOSED TO ACUTE INTERMITTENT HYPOBARIC HYPOXIA
}

\author{
S. DEWI ${ }^{1 凶}$, M. SADIKIN 1, W. MULYAWAN ${ }^{2}$ \\ ${ }^{1}$ Department of Biochemistry and Molecular Biology, Faculty of Medicine, \\ Universitas Indonesia, Jakarta, Indonesia; \\ ${ }^{2}$ Department of Aerophysiology, Lakespra Saryanto, \\ Air Force Indonesian National Army, Jakarta, Indonesia;

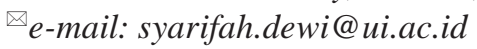

Received: 01 October 2020; Accepted: 17 May 2021

It is known that the altitude area causes hypoxic conditions due to the low oxygen partial pressure. This study was conducted to estimate oxidative stress indices in the heart tissue after Wister rats exposure to the acute intermittent hypobaric hypoxia. Hypobaric hypoxia exposure was simulated by keeping the rats in a hypobaric chamber for 1 min at 35,000 feet altitude. After that the altitude was gradually reduced to 30,000 and 25,000 feet and maitained for $5 \mathrm{~min} .25$ male Wistar rats were divided into control group and four treatment groups (I-IV), consisting of rats exposed 1, 2, 3 and 4 times to hypobaric hypoxia with a frequency once a week. The animals were removed from the experiment at the height of 18,000 feet and the heart tissue was obtained. The carbonyl groups and MDA levels and superoxide dismutase and catalase activity were examined in the supernatant of the heart tissue homogenate. In the samples of group I, the decrease in catalase activity with a simultaneous notable increase in carbonyl groups level was observed compared to control. In the samples of groups III and IV, the carbonyl level normalized and the activity of both antioxidant enzymes increased significantly. It was concluded that the increase of antioxidant enzymes activity can contribute to cardiac tissue adaptive response to acute hypobaric hypoxia exposure.

Ke y wo rd s: acute intermittent hypobaric hypoxia, heart, oxidative stress, antioxidant enzymes.

$\mathrm{H}$ igh altitude can result in hypoxia because of decrease oxygen partial pressure (hypobaric hypoxia). Physiological responses will be performed from cellular to molecular to adapt to low oxygen level. The altitude, that stimulates the physiological changes that significantly affect cardiopulmonary performance, typically begins at higher than $2500 \mathrm{~m}$ [1]. These physiological changes include increase in erythrocyte number and blood oxygen transport capacity, change in cardiac output and metabolic modifications at the cellular level [1,2].

Hypobaric hypoxia causes increase in reactive oxygen species (ROS) production, hence increase in oxidative damage caused by ROS attacks on the macromolecules such as lipids, proteins and DNA [3]. Reactive oxygen species act as free radicals that attack carbon-carbon double bonds in lipids, espe- cially polyunsaturated fatty acids (PUFAs) resulting in lipid peroxidation. Malondialdehyde is one of lipid peroxidation markers [4]. Free radicals can also attack protein molecules resulting in carbonylation of protein and carbonyl substance is a marker [5].

Oxidative stress is a condition whenever the free radicals (ROS) production is higher than antioxidant defenses. In our body, it has been completed by ROS scavenger system including antioxidant enzymes. Superoxide dismutase is a family of antioxidant enzymes which catalyzes the dismutation of superoxide radical anion into hydrogen peroxide and oxygen [6]. Catalase, one endogenous antioxidant enzymes, will catalyze the rapid decomposition of hydrogen peroxide into water [7]. Some previous studies have demonstrated that rats placed in a hypobaric chamber experience increased oxidative stress

(C) 2021 Dewi S. et al. This is an open-access article distributed under the terms of the Creative Commons Attribution License, which permits unrestricted use, distribution, and reproduction in any medium, provided the original author and source are credited. 
as results of hypoxia exposure $[8,9]$. Another study reported that oxidative stress is increased after both acute and chronic exposure to high altitude [10].

In the Indonesia air force army, there is routine training to high altitude exposure using a hypobaric chamber. This training is purposed to induce adaptation and detect hypoxia condition whenever the fighter plane is operated. Air operation at high altitudes has a risk for its crew from the physical, physiological and psychological disturbances, which may occur at sudden high altitude [11]. The exact analytical skills as a combat pilot are very important, so it needs to be trained in hypoxic conditions. But there is no study to evaluate the effects of this training in the future, especially that occur in heart organ. So in this study, we investigated the impact of acute intermittent hypobaric hypoxia on oxidative stress status (oxidative marker and antioxidant) in heart organ to predict heart health in the future.

\section{Materials and Methods}

Experimental design. The experiments were performed in vivo at Biochemistry and Molecular Biology Laboratory, Faculty of Medicine University of Indonesia and Aerophysiology Laboratory in Lakespra Saryanto TNI AU. Samples were 25 male Wistar rats (6-8 weeks old) which determined with Federer formula. Rats were randomly divided into 5 groups ( $n=5$ per group): a control group (without altitude simulation) and four treatment groups (with altitude simulation). The treatment groups were exposed to acute hypobaric hypoxia by placing rats into the hypobaric chamber once a week. Group I was exposed 1 time, group II -2 times, group III -3 times and group IV - four times. All rats had meal and water ad libitum. Protocol of hypobaric hypoxia was designed for altitude studies and air force soldiers' special training. Hypobaric hypoxia exposure given is a simulation of altitude at 35,000 feet for $1 \mathrm{~min}$. After that, the altitude is gradually reduced to 30,000 and 25,000 feet and it maintained for $5 \mathrm{~min}$. The rats were sacrificed at height of 18,000 feet and the heart organs were collected. Flight/altitude simulation is described in Fig. 1.

Tissue preparation. The heart organ was weighed as much as $100 \mathrm{mg}$ and homogenized in $1000 \mathrm{uL}$ phosphate buffer saline (PBS) $0.01 \mathrm{M}$ $\mathrm{pH}$ 7.4. The homogenate was centrifuged at $3000 \mathrm{rpm}$ for $10 \mathrm{~min}$ and the supernatant was kept. This supernatant was used for measurement of MDA, carbonyl, specific activity of SOD and cata-

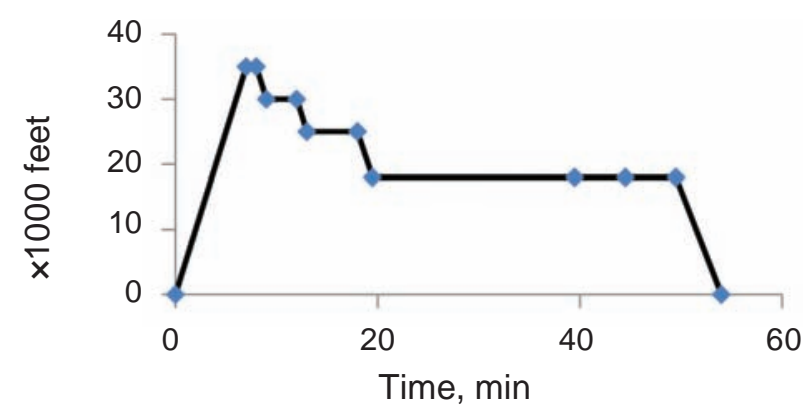

Fig. 1. Scheme of flight/altitude simulation using hypobaric chamber

lase. The supernatant was added with PMSF (phenylmethylsulfonyl fluoride) as a protease inhibitor in examination of specific activity of SOD and catalase.

Examination of MDA level. The measuring MDA level was conducted using the Wills method. Thiobarbituric acid (TBA) reacts with MDA giving pink color. Standard curve is produced using tetra ethoxy propane (TEP) diluted by water 1: 80,000 as standard solution. Samples were added with trichloroacetic acid (TCA) 20\% to precipitate protein. After centrifugation at $6000 \mathrm{rpm}$ for $5 \mathrm{~min}$, the supernatant was collected. Thiobarbituric acid $0.67 \%$ was added to supernatant and incubated at boiling water $95-100^{\circ} \mathrm{C}$. Pink color arose appropriate to MDA level and the color was read by spectrophotometer at $530 \mathrm{~nm}$.

Examination of carbonyl level. Examination of carbonyl level was conducted using 2,4-dinitrophenylhydrazine (DNPH) that react with carbonyl substances in samples giving yellow color [12]. The samples were added with $10 \mathrm{mM}$ DNPH in $2.5 \mathrm{M}$ $\mathrm{HCl}$ and incubated in dark at room temperature. Trichloroacetic acid (TCA) 20\% was added to the samples and incubated on ice for $5 \mathrm{~min}$. After that, it was centrifuged at $10.000 \mathrm{~g}$ for $10 \mathrm{~min}$ and the supernatant discarded. Subsequently, TCA $10 \%$ was added and incubated on ice for $5 \mathrm{~min}$. The supernatant was discarded after centrifugation of samples at $10.000 \mathrm{~g}$ for $10 \mathrm{~min}$. The pellet was resuspended in ethanol : ethyl acetate solution (1:1). Guanidine $\mathrm{HCl}$ was added and the yellow color arose. The absorbance was read at wavelength $360-385 \mathrm{~nm}$. The carbonyl level is presented per mg of protein.

Examination of SOD specific activity. Examination of specific activity of SOD enzyme was conducted using RanSOD kit, Randox ${ }^{\circledR}$. This kit generates superoxide anion through reaction xanthine with uric acid which catalyzed by xanthine oxidase. 
Superoxide anion reacts with 2-(4-iodophenyl)-3-(4nitrophenol)-5-phenyl tetrazolium chloride (I.N.T) and results in a red formazan dye. This color was read by spectrophotometer at $505 \mathrm{~nm}$. If the sample contains some activities of SOD, then the color formed is reduced as much as superoxide anion also reduced. The activity of SOD enzyme is obtained by the subtraction of the absorbance between the first reading (30 sec after samples mixing) and the second reading ( 3 min later after the first reading). The specific activity of SOD is resulted from enzyme activity (U/ml) divided by total protein concentration (mg/ml).

Examination of catalase specific activity. Examination of specific activity of catalase was conducted using hydrogen peroxide $\left(\mathrm{H}_{2} \mathrm{O}_{2}\right)$ which added to samples [13]. Catalase enzyme breaks down hydrogen peroxide into oxygen and water. Hydrogen peroxide has a high absorbance at $240 \mathrm{~nm}$. The activity of catalase enzyme was obtained by the reduction of the absorbance between the first reading ( $30 \mathrm{sec}$ after samples mixing) and the second reading ( 3 min later after first reading). The reduction of absorbance is appropriate with decreasing hydrogen peroxide. The specific activity of catalase is resulted from enzyme activity $(\mathrm{U} / \mathrm{ml})$ divided by total protein concentration (mg/ml).

Statistical analysis. Statistical analysis was performed using SPSS software version 20. The obtained data were normally distributed, therefore we analyzed the data using independent t-test to com- pare each treatment group to control group, significant if $P<0.05$. Data were presented by bar chart showing mean $\pm \mathrm{SD}$.

\section{Results and Discussion}

Malondialdehyde level in rat's heart can be seen in Fig. 2 after exposure to acute intermittent hypobaric hypoxia. In group I, II and III, there is no significant difference in MDA level compared to the control group. Only in group IV, the MDA level is significantly increased $(P<0.05)$ compare to control group. Carbonyl level shows that the significant increase occurs in group I $(P<0.001)$ compared to the control group. However, in group II, III and IV, carbonyl level decreases near to the control group (Fig. 3).

Specific activity of SOD in rat's heart shows that an increasing activity along to the number of repeated exposures. There are not significant activity differences in group I and II, but there is significant increase in group III $(P<0.05)$ and IV $(P<0.001)$ compare to the control group (Fig. 4). Specific catalase activity in rat's heart after hypobaric hypoxia exposure demonstrated significant decrease in group I $(P<0.05)$ compared to control group, and gradual increase in group II, III and IV. Significant increase is found in group III $(P<0.05)$ and group IV $(P<0.001)$ compared to the control group (Fig. 5).

Oxidative stress is resulted from a higher state of prooxidant or free radicals compare to antioxidant

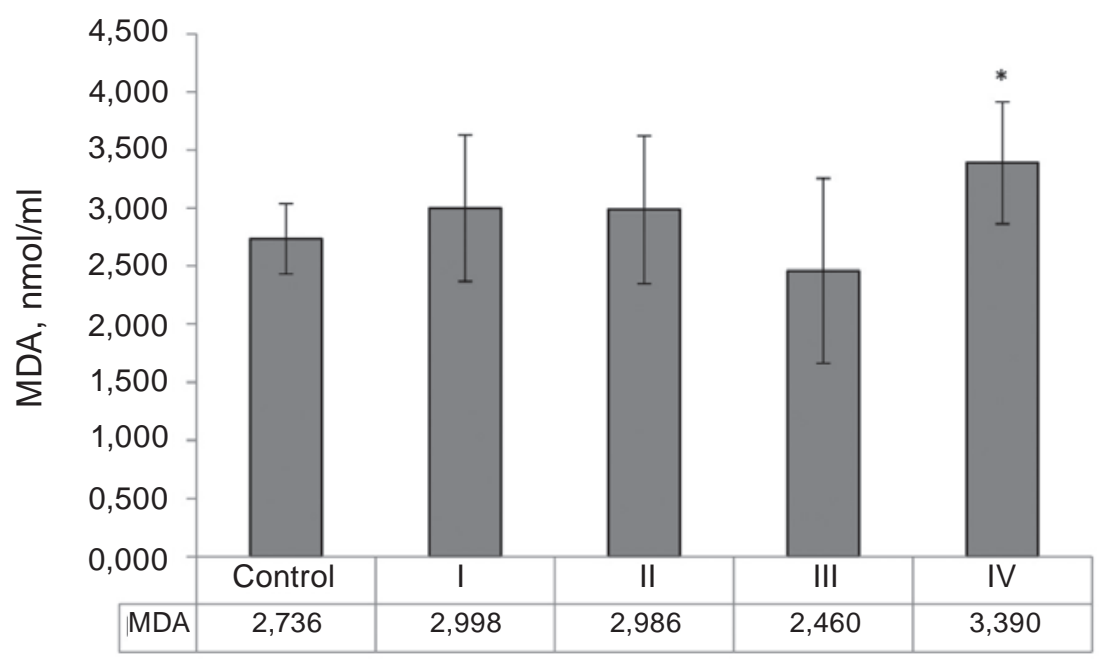

Fig. 2. MDA level in rat heart after acute intermittent hypobaric hypoxia exposure. Control group - no treatment; group I, II, III and IV-experiment groups with hypobaric hypoxia exposure 1, 2, 3 and 4 times, respectively (mean $\pm S D$ ). The difference is statistically significant compared to the control group (independent t-test, $* P<0.05)$ 


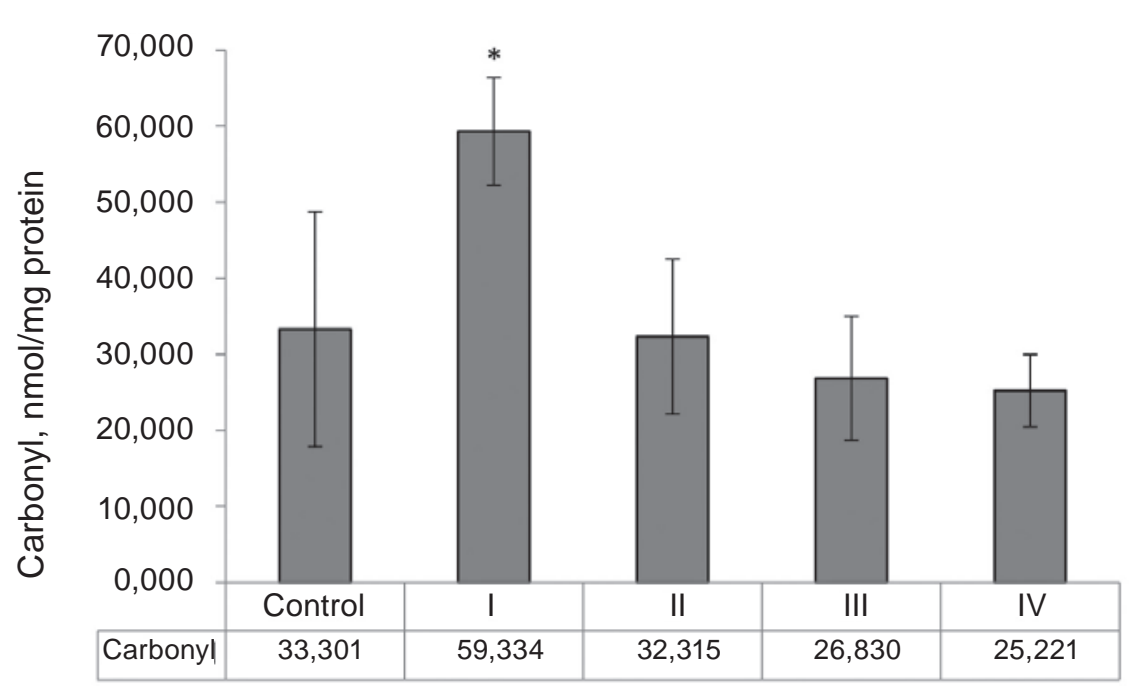

Fig. 3. Carbonyl level in rat heart after acute intermittent hypobaric hypoxia exposure. Control group - no treatment; group I, II, III and IV - experiment groups with hypobaric hypoxia exposure 1, 2, 3 and 4 times, respectively (mean $\pm S D$ ). The difference is statistically significant compared to control group (independent t-test, $* P<0.05)$

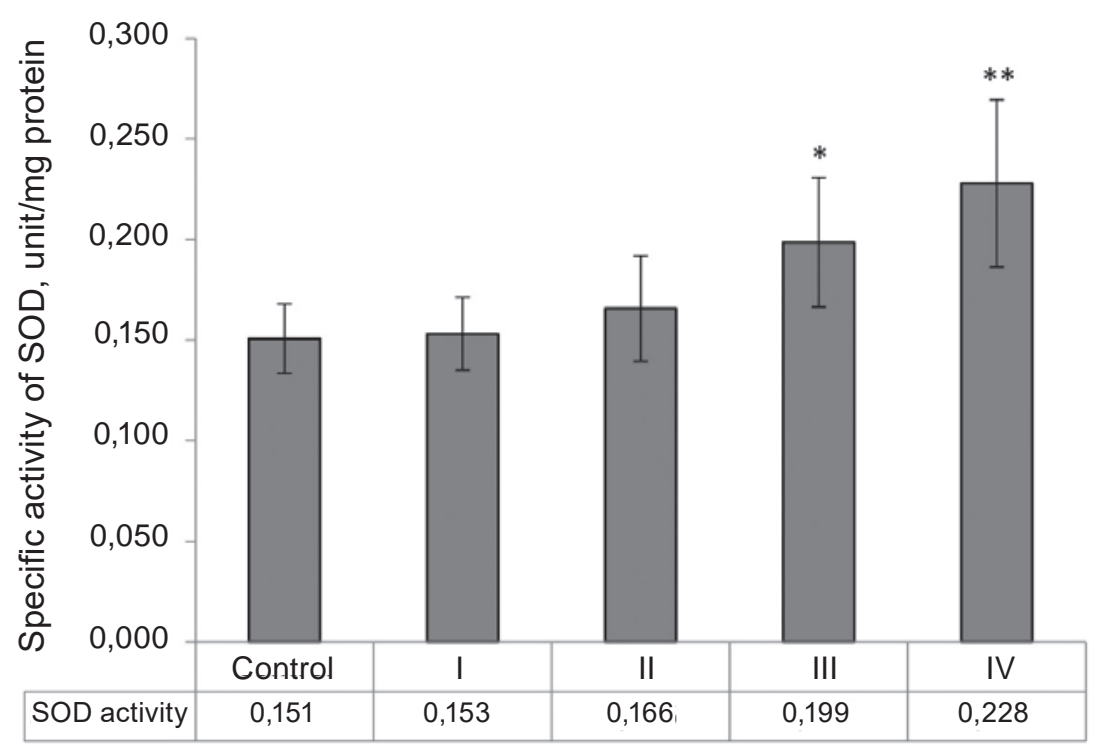

Fig. 4. Specific activity of SOD in rat heart after acute intermittent hypobaric hypoxia exposure. Control group - no treatment; group I, II, III \& IV-experiment groups with hypobaric hypoxia exposure 1, 2, 3 and 4 times, respectively (mean $\pm S D$ ). The differences are statistically significant compared to the control group (independent t-test, ${ }^{*} P<0.05,{ }^{* *} P<0.001$ )

as free radical scavenger, hence causes oxidative damage in cells or tissues. MDA has been widely used as biomarker of lipid peroxidation. It arises largely from peroxidation of polyunsaturated fatty acids (PUFAs) with more than two double bonds, such as linolenic, arachidonic and docosahexaenoic acids. Besides MDA, lipid peroxidation also forms aldehydes such as propanal, hexanal and 4-hydroxynonenal (4-HNE). Results of MDA level in rat heart after acute intermittent hypobaric hypoxia exposure show no significant difference in MDA level between group I, II, III and control. Only group IV has significant increase in MDA level compared to the control group. It seems that acute intermittent hypobaric hypoxia exposure increases ROS production compared to the control group, although it increases in the late exposure group. In this study, we measure MDA level by TBA (thiobarbituric) test that yields 


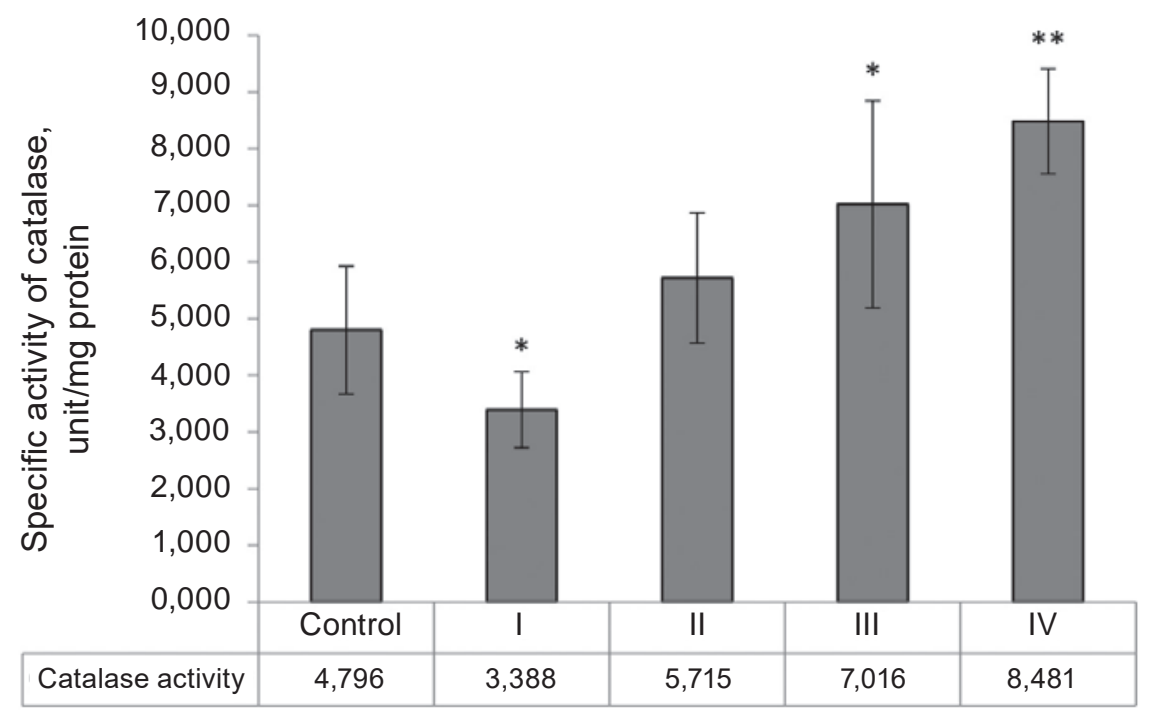

Fig. 5. Specific activity of catalase in rat heart after acute intermittent hypobaric hypoxia exposure. Control group - no treatment; group I, II, III and IV - experiment groups with hypobaric hypoxia exposure 1, 2, 3 and 4 times, respectively (mean $\pm S D$ ). The differences are statistically significant compared to control group (independent $t$-test, $* P<0.05, * * P<0.001$ )

pink color. The TBA test is one of the oldest and the most frequently used for measuring lipid peroxidation, but it has controversy in MDA quantification from in vivo samples because it is not specific [4]. However, TBA test is quite sensitive and easy to conduct.

The two most frequent ROS which affect biomolecules are hydroxyl radical (HO') and hydroperoxyl radical $\left(\mathrm{HO}_{2}{ }^{\circ}\right)$. Hydroxyl radical $\left(\mathrm{HO}^{\circ}\right)$ is generated through Fenton reaction, where free iron $\left(\mathrm{Fe}^{2+}\right)$ reacts with hydrogen peroxide $\left(\mathrm{H}_{2} \mathrm{O}_{2}\right)$ [14]. Carbonyl compounds are derived from the oxidation of carbohydrates, lipids, and amino acids. The result of carbonyl level shows a different pattern to MDA in this study. Carbonyl level is significantly increased in early exposure group (I) compared to the control group. After that, the carbonyl is decreased parallel to the repeated exposure (II, III and IV). It proves that the repeated hypobaric hypoxia exposure decreases the carbonyl level in the heart organ.

The antioxidant enzymes measured in this study, SOD and catalase, have significantly increased parallel to repeated exposure number (group III and IV). Hypoxia exposure promotes ROS production because of lack oxygen that can inhibit the electron transport chain in mitochondria, hence increasing superoxide radicals generation at complex III [15]. Therefore why catalase enzyme activity decreased in the early exposure group, although SOD activity is not different from the control group. Another study demonstrated increased ROS and RNS production after high altitude exposure [16]. However, we found an increasing SOD and catalase activity in repeated exposure groups (III and IV). It shows that repeated or intermittent hypobaric hypoxia exposure stimulate an adaptation response, especially antioxidant defenses toward free radicals (ROS) generation.

Previous study reported that repeated hypoxia exposure could induce an adaptation to oxidative stress. A study using rat brain shows that intermittent hypobaric hypoxia exposure stimulates an adequate adaptive response that proven by significantly increasing of specific activity of SOD and catalase and decreasing of MDA and carbonyl level [17]. Other study demonstrated that intermittent hypoxia promotes preconditioning-like effects and enhances the susceptibility of the heart to oxidative stress, which is characterized by increased thioredoxin levels and decreased oxidative markers [18].

Based on the result, it is concluded that heart organ produces an adaptive response to acute intermittent hypobaric hypoxia, demonstrated by decreased carbonyl level and increased specific activity of SOD and catalase.

Conflict of interest. Authors have completed the Unified Conflicts of Interest form at http://ukr- 
biochemjournal.org/wp-content/uploads/2018/12/ coi_disclosure.pdf and declare no conflict of interest.

Acknowledgement. This study was supported by Hibah Publikasi Terindeks Internasional Q3 (PUTI Q3) 2020 from Directorate of Research and Community Services Universitas Indonesia.

\section{ОКСИДАТИВНИЙ СТРЕС У СЕРЦІ ЩУРІВ ІЗ ГОСТРОЮ ГІПОБАРИЧНОЮ ГІПОКСІЄЮ}

S. Dewi ${ }^{1 \bowtie}$, M. Sadikin ${ }^{1}$, W. Mulyawan ${ }^{2}$

${ }^{1}$ Department of Biochemistry and Molecular Biology, Faculty of Medicine,

Universitas Indonesia, Jakarta, Indonesia;

${ }^{2}$ Department of Aerophysiology, Lakespra Saryanto, Air Force Indonesian National Army, Jakarta, Indonesia; 『e-mail: syarifah.dewi@ui.ac.id

Відомо, що висотна зона спричинює гіпоксію через низький парціальний тиск кисню. У дослідженні оцінено показники окисного стресу в тканині серця щурів лінії Вістар за гострої переривчастої гіпобаричної гіпоксії. Гіпобаричну гіпоксію змодельовано перебуванням тварин у гіпобаричній камері на висоті 10,7 км (35000 футів) протягом 1 хв. Висоту поступово зменшували до 9,1 та 7,6 км (30000 та 25000 футів) та утримували протягом 5 хв. Щурів (25 самців) було розподілено на контрольну та чотири експериментальні (I-IV) групи тварин, яких піддавали гіпобаричній гіпоксії відповідно 1, 2, 3 та 4 рази $з$ частотою один раз на тиждень. На висоті 5,5 км (18000 футів) тварин видаляли з експерименту та одержували супернатант гомогенату тканини серця для оцінки рівня МДА та карбонільних груп, активності супероксиддисмутази та каталази. У зразках тварин групи I було виявлено зниження активності каталази за одночасного істотного підвищення рівня карбонільних груп порівняно з контролем. У зразках III та IV груп рівень карбонільних груп нормалізувався, а активність супероксиддисмутази та каталази значно зростала. Дійшли висновку, що підвищення активності антиоксидантних ензимів сприяє адаптаційній реакції серцевої тканини на гостру гіпобаричну гіпоксію.

Кл ю ч о в с слова: гостра переривчаста гіпобарична гіпоксія, серце, оксидативний стрес, антиоксидантні ензими.

\section{References}

1. Donegani E, Hillebrandt D, Windsor J, Gieseler U, Rodway G, Schöffl V, Küpper T. Pre-existing cardiovascular conditions and high altitude travel. Travel Med Infect Dis. 2014; 12(3): 237-252.

2. Bärtsch P, Gibbs JSR. Effect of altitude on the heart and the lungs. Circulation. 2007; 116(19): 2191-2202.

3. Bakonyi T, Radak Z. High altitude and free radicals. J Sports Sci Med. 2004; 3(2): 64-69.

4. Ayala A, Muñoz MF, Argüelles S. Lipid peroxidation: production, metabolism, and signaling mechanisms of malondialdehyde and 4-hydroxy-2-nonenal. Oxid Med Cell Longev. 2014; 2014: 360438.

5. Grimsrud PA, Xie H, Griffin TJ, Bernlohr DA. Oxidative stress and covalent modification of protein with bioactive aldehydes. Biol Chem. 2008; 283(32): 21837-21841.

6. McCord JM, Edeas MA. SOD, oxidative stress and human pathologies: a brief history and a future vision. Biomed Pharmacother. 2005; 59(4): 139-142.

7. Al-Abrash AS, Al-Quobaili FA, Al-Akhras GN. Catalase evaluation in different human diseases associated with oxidative stress. Saudi Med J. 2000; 21(9): 826-830.

8. Møller P, Loft S, Lundby C, Olsen NV. Acute hypoxia and hypoxic exercise induce DNA strand breaks and oxidative DNA damage in humans. FASEB J. 2001; 15(7): 1181-1186.

9. Esteva S, Pedret R, Fort N, Torrella JR, Pagès T, Viscor G. Oxidative stress status in rats after intermittent exposure to hypobaric hypoxia. Wilderness Environ Med. 2010; 21(4): 325-331.

10. Jefferson JA, Simoni J, Escudero E, Hurtado ME, Swenson ER, Wesson DE, Schreiner GF, Schoene RB, Johnson RJ, Hurtado A. Increased oxidative stress following acute and chronic high altitude exposure. High Alt Med Biol. 2004; 5(1): 61-69.

11. Cmde A, Tyagi P, Cmde A, Malik H. Suggested operating schedules for sudden induction of unacclimatized or partially acclimatized aircrew for air operations at high altitude. Indian $J$ Aerosp Med. 2008; 52(2): 9-14.

12. Levine RL, Williams JA, Stadtman EP, Shacter E. Carbonyl assays for determination of oxidatively modified proteins. In: Methods in Enzymology. 1994: 346-357. 
13. George P. Reaction Between Catalase and Hydrogen Peroxide. Nature. 1947; 160(4054): 41-43.

14. Birben E, Sahiner UM, Sackesen C, Erzurum S, Kalayci O. Oxidative stress and antioxidant defense. World Allergy Organ J. 2012; 5(1): 9-19.

15. Bleier L, Dröse S. Superoxide generation by complex III: from mechanistic rationales to functional consequences. Biochim Biophys Acta. 2013; 1827(11-12): 1320-1331.

16. Magalhães J, Ascensão A, Soares JMC, Ferreira R, Neuparth MJ, Marques F, Duarte JA. Acute and severe hypobaric hypoxia increases oxidative stress and impairs mitochondrial function in mouse skeletal muscle. J Appl Physiol. 2005; 99(4): 1247-1253.

17. Dewi S, Mulyawan W, Wanandi SI, Sadikin M. The Effect of Intermittent Hypobaric Hypoxia on Oxidative Stress Status and Antioxidant Enzymes Activity in Rat Brain. Acta Biochim Indones. 2018; 1(2): 46-51.

18. Park AM, Suzuki YJ. Effects of intermittent hypoxia on oxidative stress-induced myocardial damage in mice. J Appl Physiol. 2007; 102(5): 1806-1814. 